\title{
RAPD ANALYSIS OF CALLUS REGENERATED AND SEED GROWN PLANTS OF MAIZE (Zea mays L.)
}

\author{
MARIA JOSE VILAÇA DE VASCONCELOS ${ }^{1}$, MAURICIO SCHUSTERSCHITZ ANTUNES ${ }^{2}$, \\ SOLANGE MARQUES BARBOSA ${ }^{3}$ e CARLOS HENRIQUE SIQUEIRA DE CARVALHO ${ }^{4}$
}

\author{
${ }^{1}$ Embrapa Maize and Sorghum, Caixa Postal 151, CEP 35701-970, Sete Lagoas, MG. E-mail: \\ mjose@cnpms.embrapa.br (Correspondent author) \\ ${ }^{2}$ Bolsista DTI RHAE/CNPq \\ ${ }^{3}$ Bolsista Iniciação cientifica/Fapemig \\ ${ }^{4}$ Embrapa Café
}

Revista Brasileira de Milho e Sorgo, v.7, n.2, p. 93-104, 2008

\begin{abstract}
Genetic and cytogenetic changes are frequently observed in plants regenerated from tissue culture. This phenomenon, termed somaclonal variation, is undesirable in genetic transformation processes. DNA-based molecular markers have been used to characterize and evaluate genetic variability among individuals. The RAPD technique was used to evaluate somaclonal variation in maize plants derived from tissue culture from the maize inbred line L48 (derived from Suwan). Forty seven different decamer oligonucleotide primers generated 221 amplification products, 130 of them being polymorphic. Genetic divergence was calculated by the Nei's distance based on the presence (1) or absence (0) of DNA bands in the different analyzed samples. Cluster analyses divided the samples into three distinct groups, considering an upper limit of 0.38 genetic distances. The first group included the tissue culturederived calli, the second one the regenerated plants, and the seed-derived plants formed the last group. The results indicated that segregation was still present in the inbred line L48 after six cycles of selfing and/or that different clones of the same age accumulated different types of genetic modifications ( 0.05 of genetic distance). These modifications seem to be directly correlated with the potential for callus regeneration. As the age of the callus increased from 13 to 25 months, regeneration decreased about 28 times. These results indicate that RAPD technique can be used as a potent and easy-to-use tool to identify maize inbred lines less susceptible to somaclonal variation when cultured in vitro, a fundamental step in plant genetic transformation
\end{abstract}

Key words: Genetic variability, somaclonal variation, somatic embryogenesis, tissue culture.

\section{ANÁLISE MOLECULAR EM CALOS REGENERADOS E PLANTAS OBTIDAS DE SEMENTES DE MILHO (Zea mays L.)}

RESUMO - Variações em genética e citogenética são frequentemente observadas em plantas regeneradas em cultura de tecidos. Esse fenômeno, chamado variação somaclonal, é indesejável nos processos de transformação genética. Marcadores 
moleculares baseados em DNA têm sido amplamente usados para caracterizar e avaliar variabilidade genética entre indivíduos. Foi usada a técnica de RAPD para avaliar a variação somaclonal em plantas de milho derivadas de cultura de tecidos e sementes da linhagem L48 (derivada de Suwan). Quarenta e sete diferentes oligonucleotídeos decâmeros geraram 221 produtos de amplificação, 130 polimórficos. Divergência genética foi calculada usando distância de Nei, baseada na presença (1) e ausência (0) de produtos de amplificação de DNA. Análises de clusters dividiram as amostras em três grupos distintos, considerando o limite superior de $38 \%$ de distancia relativa. $\mathrm{O}$ primeiro grupo, incluiu os calos derivados de cultura de tecido, o segundo, as plantas regeneradas e o terceiro e ultimo, as plantas derivadas de semente. Os resultados indicaram que a linhagem L48 após seis ciclos de autofecundação e/ou de diferentes clones da mesma idade, acumulou diferentes tipos de variação genética. Com o aumento da idade dos calos de 13 para 25 meses, a regeneração diminuiu cerca de 28 vezes. Esses resultados indicaram que a técnica de RAPD pode ser usada como uma potencial e fácil ferramenta para identificar linhagens menos susceptível à variação somaclonal, quando cultivada in vitro, fundamental etapa para transformação genética.

Palavras-chave: Embriogênese somática, variabilidade genética, variação somaclonal, cultura de tecidos

Tissue culture techniques are commonly used for the propagation of many plant species, and are a fundamental step in transformation and genetic engineering processes. It is known that in many cases, a consistent proportion of the regenerated plants differ from the original parental type when submitted to tissue-culture techniques. This phenomenon is called "somaclonal variation" (Larkins and Scowcroft, 1981). Although such variation may provide useful source of genetic variability for crop improvement, it is undesirable in plant propagation and genetic transformation. A better understand for somaclonal variation is necessary to assess the potential usefulness of the tissue-culture techniques (Armstrong and Phillips, 1988), and also to develop methods whereby the material can be easily and rapidly screened to reveal any genetic difference from non tissue culture-derived controls (Brown et al., 1993; Saker et al, 2000; Raimondi et al., 2001).
Genetic variation depends of the plant species, the genotype involved, the type of explant, and the culture media and conditions (Karp and Bright, 1985; Shuangxia et al., 2008). These alterations may involve genomic, chromosomal and gene mutation (D'Ámato, 1985), activation of transposable elements, or changes in methylation pattern (Brown, 1998). Amplification of repetitive sequences was found in de-differentiating cells of Nicotiana glauca (Durante et al., 1983), in double haploids of $N$. silvestris (DePaepe et al., 1982) and N. tabacum (Dhillon et al., 1983). Variation in ribosomal DNA amount has been reported in regenerated plant of Solanum tuberosum (Landsmann and Uhrig, 1982) and Triticale (Brettell et al., 1986). A correlation between tissue culture stress and transposition has been shown for the Ac element in maize cultures (Peschke et al., 1987). DNA rearrangement and methylation pattern change where observed in rice regenerants by Muller et al. (1990) and in pea by Cecchine et al. (1992). 
Karyological analysis of plant can very often revel significant chromosomal changes (Karp and Bright, 1985) but can not reveal alterations in individual genes. Procedures such as isozyme analysis provide a relatively convenient method for examining biochemical changes although they are usually limited by the number of available markers (Brown et al., 1993). A precise determination of changes in a particular gene sequence resulting from tissue culture can be obtained by RFLP analysis. However, this method is time consuming and very expensive, and the results are limited only to gene sequences used as probes (Brown et al., 1993).

The development of the polymerase chain reaction (PCR) has been one of the major technical advances in molecular biology in recent years. RAPD known as random amplification polymorphic DNA or arbitrarily PCR (RT-PCR), allows the amplification of discrete fragment of the genome without the previous knowledge of their sequences. These fragment can be used as genetic marker to determine differences among individuals at the DNA level (Williams et al., 1990; Welsh et al., 1990; Vasconcelos et al., 1996; AL-Zahim et al., 1999; Jayanthi and Mandal, 2001; Raimondi et al., 2001; Paduan et al., 2006; Shuangxia et al., 2008).

DNA-based markers, such as a Randomly amplified polymorphic DNA (RAPD) has been used to identify somaclonal variation in banana plants propagative in vivo and in vitro and revealed genetic variation. DNA fingerprint revealed genetic variations, $25 \%$ polymorphisms, between total plants approximately $10 \%$ of the analyzed plantlets (8 regenerates). The frequency of somaclonal variation was found to be number of subcultures dependent (times of micropropagation). The genetic variations were only detected in 7 months old cultures. It was observed also that morphologically abnormal shoots and change in chlorophyll showed genetic variations at the molecular level. (EL-Dougdoug et al., 2007). Similar results were found by different groups (Muntali et al., 1996; Guo et al., 2003; Carvalho et al., 2004; Astarini et al., 2004; Ma et al., 2004).

The integration of molecular techniques, such as genetic transformation, into a plant breeding program requires the recipient plant to be genetically and morphologically suitable for inclusion in breeding trials. The tissue cultureinduced variation can comprise this requirement reducing the effectiveness of transformation (Brown et al., 1993; Saker et al, 2000).

This work showed that RAPD technique can bee easily applied to determine the levels of genetic differences in maize tissue culturederived materials, and improve our knowledge about the somaclonal variation process.

\section{Material and Methods}

\section{Genetic material, tissue culture and plant regeneration}

Maize inbred line L48 is an elite line from the breeding program of Embrapa Maize and Sorghum (Sete Lagoas, MG, Brazil), derived from BR105 - Suwan population after six cycles of selfing. All cultures were initiated from immature zygotic embryos ranging from 1.0 to $2.0 \mathrm{~mm}$ in length. Ears were surfacesterilized and the embryos were aseptically dissected out from the caryopses and plated on culture medium for callus induction and proliferation. The medium contained N6 inorganic salts (Chu et al., 1975), and was 
supplemented with sucrose $\left(30 \mathrm{gL}^{-1}\right)$, casamino acid $\left(100 \mathrm{mgL}^{-1}\right)$, glycine $(30 \mathrm{mM})$, thyamine $(15 \mu \mathrm{M})$, nicotinic acid $(7.5 \mu \mathrm{M})$, myo-inositol $(550 \mu \mathrm{M})$, proline $(6 \mathrm{mM})$, dicamba $(30 \mu \mathrm{M})$, and gelrite $\left(2.3 \mathrm{gL}^{-1}\right)$. For callus development all cultures were incubated in darkness and subcultured every 15 days. For RAPD analysis eight and 18-month old calli were used. The eight months aged calli were cultured as a pool derived from different immature embryos, as well as from individual embryos.

To induce plant regeneration callus cultures were transferred to a fresh medium with the following modifications: sucrose (20 $\left.\mathrm{gL}^{-1}\right)$, and no dicamba. After plantlets had established an adequate root system, they were potted in soil:vermiculite $(1: 1)$ and kept in the greenhouse for four weeks. Plants were regenerated from different section of the callus, selected visually as friable (type II) or semi-friable section. Table 1 shows a list of all analysed materials.

\section{DNA Extraction}

Leaves and calli were frozen in liquid nitrogen, lyophilized, and ground to a fine powder using mortar and pestle. DNA was extracted by the CTAB method according to
Saghai-Marrof et al., (1984). Each DNA was then washed with chloroform:octanol (24:1), precipitated with isopropanol and resuspended in TE buffer (10 mM Tris-HCl, $1 \mathrm{mM}$ EDTA, $\mathrm{pH}$ 8.0). RNA was removed by addition of 0.5 mg of RNAse A per sample. DNA concentration was estimated by comparing band intensity with known DNA standards on an agarose gel.

\section{DNA amplification}

Amplification reactions of $25 \mu \mathrm{L}$ contained: $10 \mathrm{mM}$ Tris- $\mathrm{HCl}(\mathrm{pH} 8), 50 \mathrm{mM} \mathrm{KCl}$, $2.5 \mathrm{mM} \mathrm{MgCl}_{2}, 0.1 \mathrm{mM}$ of each deoxynucleoside triphosphate, $0.1 \mathrm{mM}$ of one oligonucleotide decamer primer (Operon Technologies, CA, USA), $30 \mathrm{ng}$ of genomic DNA, and one unit of Taq DNA polymerase. The reactions were conducted in a thermocycler model 9600 from Perkin-Elmer Cetus (Norwalk, Conn., USA) programmed for 40 cycles, each consisting of one denaturation step $\left(94^{\circ} \mathrm{C}\right.$ for $\left.15 \mathrm{sec}\right)$, one annealing step $\left(35^{\circ} \mathrm{C}\right.$ for $\left.30 \mathrm{sec}\right)$, and one extension step $\left(72^{\circ} \mathrm{C}\right.$ for one $\left.\mathrm{min}\right)$. After the 40 th cycle one extra extension step was performed for $7 \mathrm{~min}$ at $72^{\circ} \mathrm{C}$. Amplification products were then separated on $1.2 \%$ agarose gels containing ethidium bromide, visualized under UV light and photographed using Polaroid film type

TABLE 1. Genetic Materials Source of plant tissue inbred line L48 utilized in different treatments.

\begin{tabular}{cl}
\hline Treatment & \multicolumn{1}{c}{ Source of plant tissue } \\
\hline A & L48 18 months age callus \\
B & L48 8 months age callus (derived from pool of embryos) \\
C & $\begin{array}{l}\text { L48 8 months age callus (derived from single of em- } \\
\text { bryos - clone) }\end{array}$ \\
D & L48 Leaves from seed-grown plant \\
E & $\begin{array}{l}\text { L48 Leaves from regenerated plant from friable calli } \\
\text { (type II) } \\
\text { L48 Leaves from regenerated plant from semi-friable } \\
\text { F }\end{array}$ \\
\hline
\end{tabular}


667. A total of forty-seven different primers were used in the amplification reactions.

\section{Data analysis}

Only the most intense and reproducible DNA bands were considered for analysis. They were scored as 1 (for presence) and 0 (for absence). Pairwise genetic distances among the isolates were calculated by the Percent disagreement. These data were used to cluster the isolates into defined groups based on the Unweighted pair-group method using arithmetic averages (UPGMA) with the aid of a statistical software (STATISTICA for Windows, v. 5.0).

\section{Results and Discussion}

The aim of the present study was provide RAPD markers suitable for detection of somaclonal variation in tissue cultured plants. RAPD analysis was used to determine the genetic variability among seed-grown maize plants, maize plant regenerated from tissue culture, and different types of calli. DNA amplification with forty seven different primers generated 221 bands, 130 of them were polymorphic and 91 monomorphic. Each primer produced an average of 2.7 polymorphic bands. A typical DNA amplification pattern is shown in Figure 1.

The Table 2 shows the genetic distance in the different tissues and genetic materials using Nei's distance to calculate the genetic diversity among the materials studied (Nei and Li, 1979). Genetic distances obtained within and between different tissue culture-derived samples e.g., callus culture and regenerated plants, were smaller than between callus cultures and seed grown plant (Table 2). The average of genetic distance ranged from 0.14 to 0.34 depending on the source of tissue (Table 2).

The percentage of plant regenerated from type II calli culture at different ages showed the best regeneration of 13 month old of age (Table 3). The extents of genetic variation induced by tissue culture procedures depend, among others things, upon the selection method of regeneration. Similar results about regeneration system from organized meristems showed resistant to genetic variation induced by tissue culture procedures (Vasil, 1992). Results from Kawiak et al, (2003) showed the effective method of regeneration, where no variation in plantlets $(D$. binata) regenerated through shoot-tip culture supports the fact that

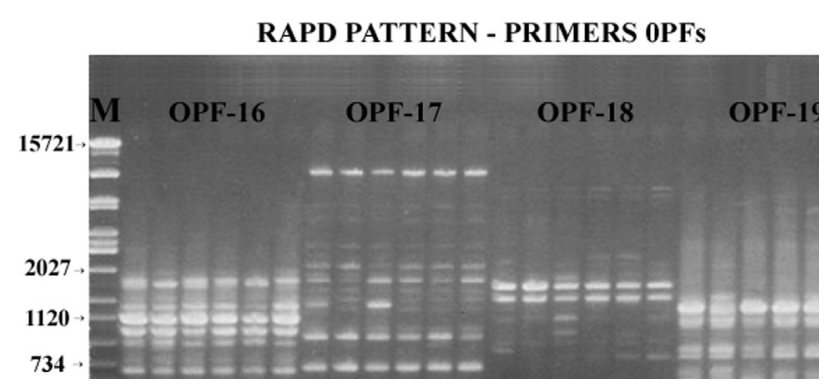

FIGURE 1. Electrophoresis pattern of DNA amplification products obtained with primers OPF-16, OPF-17, OPF-18 and OPF-19. Lane M corresponds to DNA from bacteriophage $\lambda$ digested with endonucleases EcoRI, BamHI, and HindIII, used as size markers. Lines A through F correspond to the amplification products of six different L48 genetic materials. Identification of the genetic material $(\mathrm{A} \rightarrow \mathrm{F})$ according to TABLE 1 . 
TABLE 2. Pairwise genetic distances based in Nei's distance among six sources of plant tissue derived from the maize inbred line L48. Identification of the plant tissue is according to Table 1.

\begin{tabular}{ccccccc}
\hline & $\mathbf{A}$ & $\mathbf{B}$ & $\mathbf{C}$ & $\mathbf{D}$ & $\mathbf{E}$ & $\mathbf{F}$ \\
\hline $\mathbf{A}$ & 0 & & & & & \\
$\mathbf{B}$ & 0.13 & 0 & & & & \\
$\mathbf{C}$ & 0.11 & 0.05 & 0 & & & \\
$\mathbf{D}$ & 0.32 & 0.33 & 0.34 & 0 & 0 & \\
$\mathbf{E}$ & 0.11 & 0.11 & 0.07 & 0.33 & 0.07 & 0 \\
$\mathbf{F}$ & 0.16 & 0.15 & 0.12 & 0.31 & 78.96 & \\
\hline $\begin{array}{c}\text { Coefficient } \\
\text { of deviation }\end{array}$ & 63.63 & 69.93 & 84.05 & 3.19 & & \\
\hline $\begin{array}{c}\text { Standard } \\
\text { deviation }\end{array}$ & 9.80 & 10.63 & 11.60 & 1.04 & & \\
\hline
\end{tabular}

this regeneration system preserves the genetic integrity of micropropagated plants.

We observed $5 \%$ genetic difference between the callus culture derived from one immature embryo (C) and the callus culture derived from a pool of embryos (B), indicating that segregation is still present in the inbred line L48 after six cycles of selfing. A genetic distance of $13 \%$ was obtained between eight month-old (B) and eighteen month-old (A) calli (Table 2), suggesting that genetic disturbance in the callus cells probably increase with time. These results agree with the findings of Muller et al. (1990), who demonstrated that expanding the time of rice callus cultures from 28 to 67 days resulted in a large proportion of tissue culture-derived plants with an abnormal RFLP pattern for the actin gene probe. Similar results were found by Dougdoug et al (2007) in their banana study where the frequency of somaclonal variation increases with subcultures (times of micropropagation). The genetic variations were detected in 7 months old culture. They also observed that morphologically abnormal shoots and changes in chlorophyll showed genetic variations at molecular level. Lee and Phillips (1987) and Benzion (1985) also observed an increased frequency of cytologically aberrant plants with an increase in culture age. Chuang et al. (2008), using amplified fragment polymorphism (AFLP) analysis to assess genetic fidelity primary regenerants of Echinacea purpurea derived from leaves organogenesis and their donor plants, observed $9.40 \%$ polymorphism among them.

Cluster analysis (Figure 2), using the genetic distances (Table 2) divided the samples in three distinct groups at of $38 \%$ level: the first group including callus culture (A, B, and $\mathrm{C})$; the second group, the regenerated plants (E and F); and group three with the seed-grown plant (D).

Regenerated plants from friable (E) and semi-friable (F) calli showed $7 \%$ of genetic distance. Considering that both calli cultures were submitted to the same tissue culture stress, this genetic difference can be attributed to differences inherited to the cells present in the different types of calli. According to the Armstrong and Phillips (1998), friable 


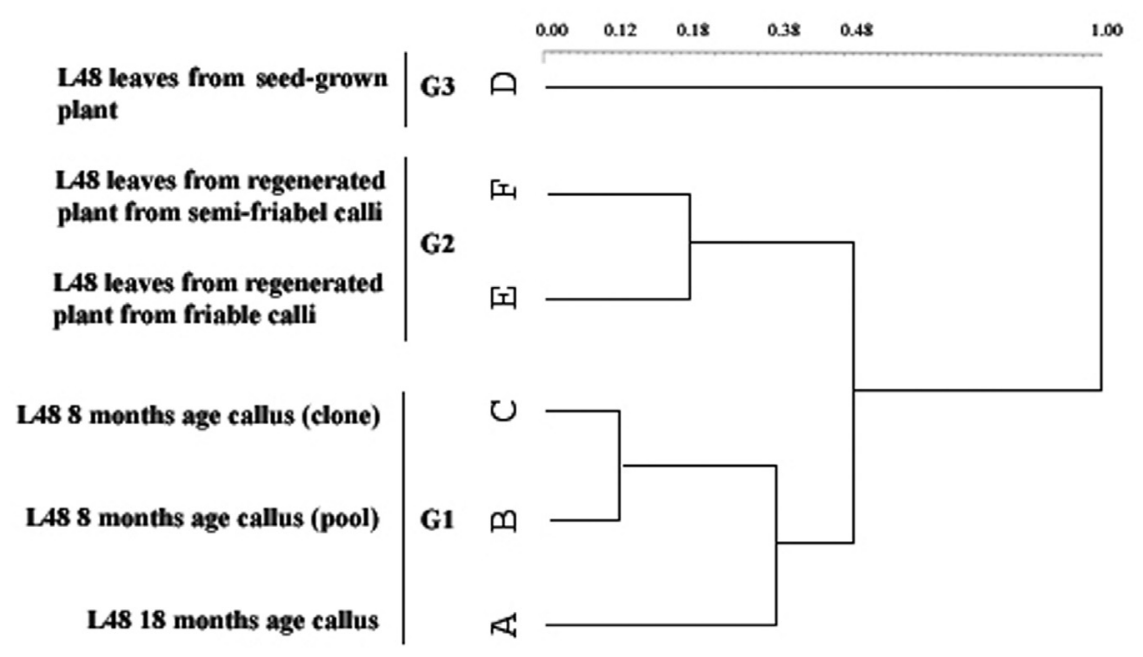

FIGURE 2. Clustering of six different L48 genetic materials based on RAPD data. Cluster divided the samples in three distinct groups at of $38 \%$ level using Nei's distance. Identification of the genetic material according to TABLE 1.

maize calli are inherently more cytologically unstable than semi-friable calli. This is in well accordance with our data which indicate that the regenerated plants from semi-friable callus were genetically closer to seed-grown plants than the regenerated plants from friable callus (Table 2).

There was genetic distance of 0.07 percent between callus and regenerated plants, and the regenerated plants were closer to seed grown plants than the calli cultures (Table 2). The higher level of variation found in maize callus culture was expected. It was a reflection of high levels of genetic polymorphism within these cultures and confirms the results of Brown et al., (1991; 1993), using RFLP and RAPD analyses, respectively. A hypothesis to explain why regenerated plants are genotypically closer to the control plants, proposed by Brown et al., (1991) is that callus cultures are genetic mosaic of cells (Edallo et al., 1981). The cells able to regenerate plants should be more resistant to somaclonal variation during the in vitro callus induction and maintenance processes, remaining as parental normal cells. To support this hypothesis, we measured the regeneration capacity in calli cultures of different ages. After one month of callus culture, 1.06 plants/ $\mathrm{g}$ of callus were regenerated, confirming that in young callus the number of embryogenic cells able to regenerate plants is small after some months of tissue culture stress acting in the callus cells. A selection of the best part of the callus is done at each callus culture, selecting embriogenic cells able to regenerate plants and increasing the proportion of these cells in relation to the total mass of the callus. Regeneration of plants has increased remarkably to 28.64 plants/g of callus in 13 month old cultures (Table 3). There is evidence that selective pressure acts in favor of plant regeneration from cytogenetically normal cells in embriogenic cultures (Swedlund and Vasil, 1985; Toncelli et al., 1985; Varshney et al., 2001; Kawiak and Lojkowska (2004); Carvalho et al., 2004). In these calli, RAPD was not 
TABLE 3. Plant regeneration from type II calli culture at different ages

\begin{tabular}{lcc}
\hline Genetic material & Callus age (months) & $\begin{array}{c}\text { Number of regenerated } \\
\text { plants/g of callus }\end{array}$ \\
\hline L48 callus & 1 & 1.06 \\
L48 callus (clone) & 13 & 27.60 \\
L48 callus (pool) & 13 & 28.63 \\
L48 callus & 25 & 0.93 \\
\hline
\end{tabular}

able to detect such normal cells, because they represented small portion of the callus. In 25 month old calli the effect of selection pressure still exist, but somaclonal variation, probably increased so much that drastically affected embriogenic cells, and subsequently affected the morphogenesis process resulting in a plant regeneration decrease of 0.93 plants/g (Table 3).

Another conclusion is that the most part of somaclonal variation occurs during the induction and maintenance phase of the callus, due to the larger period of time required by this phase and to the presence of a phytohormone, when compared to the plant regeneration step. The initiation and development of somatic embryos usually requires the presence of an auxin in the culture medium, although subsequent shoot development requires a decreased quantity or even the omission of such hormones (Green and Phillips 1975). As there is some evidence that growth regulators, especially auxin, may have an effect on chromosomal stability (Hangyel Tarezy at al., 1986), many of these genome alterations are known to occur during either the differentiation or callus formation.

As the results obtained by RAPD were expected and were confirmed in literature using other more laborious techniques, it may be inferred that this RAPD technique is reliable to detect genetic variability in explants cultivated in vitro, and it may be used in the identification of corn inbred lines that show small somaclonal variation, when cultured in tissue culture, main step to genetic transformation.

The main goal of this work was to determine the feasibility of using the RAPD as a tool to estimate somaclonal variation in maize. This is an important type of information in maize breeding programs which use plant transformation to introduce desirable genes into elite lines. Our results indicating that segregation is still present in the inbred line L48 after six cycles of selfing (Table 4) and/or those different clones of the same age accumulated different types of genetic modifications. These modifications seem to be directly correlated with the potential for callus regeneration as demonstrated on Table 3. As the age of callus increased from 13 to 25 months, regeneration decrease about 28 times.

\section{Acknowledgements}

M.S.A. and S.M.B. wishes to thank the Conselho Nacional de Desenvolvimento Científico e Tecnológico (CNPq/RHAE) and Fundação de Amparo a Pesquisa do Estado de Minas Gerais - FAPEMIG, respectively, for the DTI and IC fellowships. 


\section{Literature Cited}

AL-ZAHIM M. A.; FORD-LLOYD B. V. ; NEWBURY H. J. Detection of somaclonal variation in garlic (Allium sativum L.) using RAPD and cytological analysis. Plant Cell Reports, Berlin, v. 18, s.6 p. 473-477, 1999.

ASTARINI I. A.; PLUMMER J. A.; LANCASTER R. A. et al., Fingerprinting of cauliflower cultivars using RAPD markers. Australian Journal of Agricultural Research, Victoria, v. 55, p. 117-124, 2004.

ARMSTRONG, C. L.; PHILLIPS, R. L. Genetic and cytogenetic variation in plants regenerated from organogenic and friable, embryogenic tissue cultures of maize. Crop Science, Madison, v. 28 p. 363-369, 1988.

BENZION, G. Genetic and cytogenetic analysis of maize tissue cultures: a cell line pedigree analysis. Dissertation Abstracts International. Section B. Physical Sciences and Engineering, Ann Arbor, v. 45, n. 9 , p. 2756-2757, 1985.

BRETTELL, R. I. S.; PALLOTTA, M. A.; GUSTAFSON, J. P.; APPELS, R. Variation at the Nor loci in triticale derived from tissue culture. Theoretical Applied Genetic, Berlin, v. 7, p. 637-643, 1986.

BROWN, P. T. H. DNA methylation in plants and its role in tissue culture. Genome, Ottawa, v. 31, p. 717-729, 1998.

BROWN, P. T. H.; LANGE, F. D.; KRANZ, E.; LÖRZ, H. Analysis of single protoplasts and regenerated plants by PCR and RAPD technology. Molecular Genetics and Genomics, New York, v. 237, p. 311-317, 1993.

BROWN, P. T. H.; GÖBEL, E.; LÖRZ, H. RFLP analysis of Zea mays callus cultures and their regenerated plants. Theoretical and Applied Genetics, Berlin, v. 81, p. 227-232, 1991

CARVALHO L. C.; OLIVEIRA, L. G. C. et al., RAPD assessment for identification of clonal identity and genetic stability of in vitro propagated chestnut hybrids. Plant Cell Tissue Organ Culture, The Hague, v.77, p. 23-27, 2004.

CHU, C. C.; WANG, C. C.; SUN, C. S.; HSU, C.; YIN, K. C.; CHU, C. Y.; BI, F.Y. Establishment of an efficient medium for anther culture of rice through comparative experiments on the nitrogen sources. Scientia Sinica, Peking v. 18, p. 659-668, 1975

CECCHINI, E.; NATALI, L.; CAVALLINI, A.; DURANTE, M. DNA variations in regenerated plants of pea (Pisum sativum L.). Theoretical and Applied Genetics, Berlin, v. 84, p. 874879, 1992.

D'AMATO, F. Cytogenetics of plant cell and tissue cultures and their regenerates. CRC Critical Reviews in Plant Sciences, Boca Raton, v. 3, p. 73-112, 1985.

DEPAEPE, R.; PRAT, D.; HUGUET, T. Heritable nuclear DNA changes in double haploid plants obtained from pollen culture of Nicotiana silvestris. Plant Science Letters, Amsterdam, v. 28, p. 11-28, 1982.

DHILLON, S. S.; WERNESMAN, E. A.; MISCHKE, J. P. Evaluation of nuclear DNA 
content and heterochromatin changes in antherderived dihaploids of tobacco (Nicotiana tabacum) cv Cocker 139. Canadian Journal of Genetics and Cytology, Ottawa, v. 25, p. 169-177, 1983.

DURANTE, M.; GERI, C.; GRISVARD, J.; GUILLÉ, E.; PARENTI, R.; BUIATTI, M. Variation in DNA complexity in Nicotiana glauca tissue cultures. I. Pith de-differentiation in vitro. Protoplasma, New York, v. 114, p 114-118, 1983.

EDALLO, S.; ZUCCHINALI, C.; PERENZIN, M.; SALAMINI, F. Chromosomal variation and frequency of spontaneous mutation associated with in vitro culture and plant regeneration in maize. Maydica, Bergamo, v. 26, p. 39-56, 1981.

GUO, Y. D.; YLI-MATTILA, T.; PULLI, S. Analysis of timothy (Phleum pratense L.) genetic variation with RAPD and UP-PCR. Hereditas, Lund, v.138, p.101-113, 2003.

GREEN, C. E.; PHILlIPS, R. L. Plant regeneration from tissue culture maize. Crop Science, Madison, v. 15, p. 417-421, 1975.

HANGYEL TAREZY, M.; FEHER, F.; DEAK, M. Chromosome variation of somaclones in tetraploid lucerne. Noventermeles, Budapest, v. 35 , p. $281-287,1986$

JAYANTHI, M.; MANDAL, P. K. Plant regeneration through somatic embryogenesis and RAPD analysis of regenerated plants in Tylophora indica (Burm. F. Merrill). In Vitro Cellular and Developmental Biology - Plant, Columbia, v. 37, p. 576-580, 2001.
KARP, A.; BRIGHT, S.W.J. On the causes of origins of somaclonal variation. Oxford Survey Plant Molecular and Cellular Biology, London, v. 2, p. 199-234, 1985.

KAWIAK, A.; KROLICKA, A.; LOJKOWSKA, E. Direct regeneration of Drosera from leaf explants and shoot tips. In Vitro Cellular and Developmental Biology - Plant, Columbia, v. 37, p. 175-178, 2003.

KAWIAK, A.; LOJKOWSKA, E. Application of RAPD in the determination of genetic fidelity in micropropagated Drosera plantlets. In Vitro Cellular and Developmental Biology - Plant, Columbia, v. 40, p. 592-595, 2004.

LANDSMANN, J.; UHRIG, H. Somaclonal variation in Solanum tuberosum detected at molecular level. Theoretical and Applied Genetics, Berlin, v. 71, p. 500-505, 1985.

LARKIN, P. J.; SCOWCROFT, W. R. Somaclonal variation-a novel source of variability from plant cell cultures for plant improvement. Theoretical and Applied Genetics, Berlin, v. 60, p. 197-214, 1981.

LEE, M.; PHILLIPS. R. L. Genetic variants in progeny of regenerated maize plants. Genome,Ottawa, v. 29, p. 834-838, 1987.

MA, R.; YLI-MATTILA, T.; PULLI, S. Phylogenetic relationships among genotypes of worldwide collection of spring and winter rye (Secale cereale L.) determined by RAPD-PCR markers. Hereditas, Lund, v. 140, p. 210-221, 2004.

MÜLLER, E.; BROWN, P.T.H.; HARTKE, 
S.; LÖRZ, H. DNA variation in tissue culturederived rice plants. Theoretical and Applied Genetics, Berlin, v. 80, p. 673-679, 1990.

NEI, M.; LI, W.H. Mathematical model for studying genetic variation in terms of restriction endonucleases. Proceedings of the National Academy of Sciences of the United States of America, Washington, v. 76 p. 5269-5273, 1979.

PADUAN, K. S.; ARAUJO-JUNIOR, J. P.; RIBOLLA, P. E. M. Genetic variability in geographic populations of Aedes aegypti (Diptera, Culicidae) in Brazil elucidated by molecular markers. Genetics and Molecular Biology, Ribeirão Preto, v. 29, n. 2, p. 391395, 2006.

PESCHKE, V. M.; PHILLIPS, R. L.; GENGENBACH, B. G. Discovery of transposable element activity among progeny of tissue culture- derived maize plants. Science, Washington, v. 238, p. 804-807, 1987.

RAIMONDI, J. P.; MASUELLI, R. W.; CAMADRO, E. L. Assessment of somaclonal variation in asparagus by RAPD fingerprinting and cytogenetic analyses. Scientia Horticulturae, Amsterdam, v. 90, n. 1, p. 1929, 2001.

SAGHAI-MAROOF, M. A.; SOLIMAN, R. A.; JORGENSEN, R. A.; ALLARD, R. W. Ribosomal DNA spacer-length polymorphisms in barley: Mendelian inheritance, chromosomal location, and population dynamics. Proccedings of the National Academy of Sciences of the United States of America, Washington, v. 81, p. 8014-8019, 1984.
SAKER, M. M.; BEKHEET, S. A.; TAHA, H. S.; FAHMY, A. S.; MOURSY, H. A. Detection of somaclonal variations in tissue culture - derived data palm plants using isozyme analysis and RAPD finger prints. Biological Plantarum, Prague, v. 43, p.347-351, 2000.

SHUANGXIA, J; RAMESH, M.; HUAGUO, Z.; LILI, T.; ZHONGXU, L.; YANXIN, Z.; XIANLONG, Z. Detection of somaclonal variation of cotton (Gossypium hirsutum) using cytogenetics, flow cytometry and molecular markers. Plant cell Reports, Berlin, v. 27, n. 8, p. 1303-1316, 2008.

SWEDLUND, B.; VASIL, I. K. Cytogenetic characterization of embryogenic callus and regenerated plants of Pennisetum americanum (L.). K. Schum. Theoretical and Applied Genetics, Berlin, v. 69, p. 575-581, 1985.

TONCELLI, F.; MARTINI, G.; GIOVINAZZO, G.; NUTTI RONCHI, V. Role of permanent dicentric systems in carrot somatic embryogenesis. Theoretical and Applied Genetics, Berlin, v. 70, p. 345-348, 1985.

VARSHNEY, A.; AKSHMIKUMARAN, M.; SRIVASTAVA, P. S.; DHAWAN, V. Establishment of genetic fidelity of in vitroraised Lilium bulbets through RAPD markers. In Vitro Cellular and Developmental Biology - Plant, Columbia, v. 37, p. 227-231, 2001.

VASCONCELOS, M. J. V.; BARROS, E. G.; MOREIRA, M. A. and VIEIRA, C. Genetic diversity of the common bean Phaseolus vulgaris, L. determined by DNA-based molecular markers. Brazilian Journal of 
Genetics, Ribeirão Preto v. 19, n. 3, p. 447- WILliAMS, J. G. K.; KUBELIK, A. R.; 451, 1996.

LIVAK, K. J.; RAFALSKI, J. A.; TINGEY, S.

WELSH, J.; MCCLELLAND, M. Fingerprinting V. DNA polymorphisms amplified by arbitrary genomes using PCR with arbitrary primers. Nucleic Acids Research, Oxford, v.18, n. 24, p. 7213-7218, 1991. primers are useful as genetic markers. Nucleic Acids Research, Oxford v. 18, n. 24, p. 65316535, 1991. 